\title{
Reintegration of Pakistani Return Migrants from the Middle East in the Domestic Labour Market
}

\begin{abstract}
G. M. ARIF
This study aims, first, to assess unemployment levels among both return migrants and non-migrants and, second, to examine the reintegration pattern of returnees in the domestic labour market. The study has used three data sets: the 1980 PIDE/World Bank Survey of Return Migrant Households, the 1986 ILO/ARTEP Survey of Return Migrant Households, and the 1991 Pakistan Integrated Household Survey. The results show that unemployment rates are much higher among return migrants than among non-migrants. Although this difference has narrowed with the passage of time, even among those who returned to Pakistan at least 18 months prior to the surveys, more than 10 percent of workers are unemployed. The multivariate analysis further shows that returnees, irrespective of the period elapsed since their return, are more likely to be unemployed than non-migrants. With respect to the reintegration pattern of return migrants, the study reveals that the variables indicating their human capital such as occupation and premigration and during-migration work experience appear to have greater influence on their re-absorption than the variables related to economic positions such as savings. The possibility is that unemployed returnees can not save enough from their overseas earnings to become self-employed. Provision of credit for self-employment seems to be the right way to accommodate these workers. The study also shows that the majority of workers who are able to find employment on return are satisfied with their post-return jobs and income levels, suggesting their successful reintegration in the domestic labour market.
\end{abstract}

\section{INTRODUCTION}

Since the mid-1970s Pakistan has been one of the major labour suppliers to the Middle East, where the job market is highly volatile. The annual placement of Pakistani workers in the region has fluctuated substantially, peaking in 1981 at 151,500. In the subsequent five years, it declined dramatically, from 137,300 in 1982 to only 57,800 in 1986 . Then during the period 1987-92, placements increased steadily, reaching, after the Gulf War, a record level of 195,400 in 1992. During the Islamabad.

G. M. Arif is Senior Research Demographer at the Pakistan Institute of Development Economics,

Author's Note: This paper is mainly based on my Ph.D. dissertation completed at the Australian National University, Canberra. I am thankful to my Supervisors, Dr David W. Lucas and Dr Gordon Carmichael, of the Demography Programme at ANU, and to my Adviser, Dr Charles W. Stahl, of the University of Newcastle, for their encouragement and guidance. Comments on this paper by an anonymous referee of this journal are highly appreciated. The responsibility of any error or omission in the paper lies with the author. 
last four years, it again declined from 157,700 in 1993 to 127,800 in 1996 [Akhtar (1997)]. The movement of Pakistani workers to the Middle East is by its very nature temporary. They are usually contracted to work for a fixed period of time, and at the expiry of contract, they are obliged to return home.

Concern about the ultimate return of Pakistani workers was expressed as early as 1981, when Iqbal and Khan anticipated, in their first-ever study on return migration, three kinds of return flows: return migration due to change in labour demand in the Middle East, repatriation of illegal workers, and complete exodus of Pakistanis from one or more countries because of political instability in the Middle Eastern countries [Iqbal and Khan (1981)]. While return migration influenced by change in labour demand has occurred since the mid-1980s, with the exodus of 70,000 Pakistanis from Kuwait during the 1990-91 Gulf Crisis ${ }^{1}$ and occasional repatriation of illegal workers, Pakistan has faced all three kinds of return flows anticipated by Iqbal and Khan.

In the late 1970s, the return flows of workers were less than 10 percent of the annual outflows. But the trends estimated from the airport surveys ${ }^{2}$ show that during 1982-95 the volume of return migration also fluctuated substantially, constituting 80 percent of the annual outflow in 1982 (Table 1). In the subsequent five years, on average, the return flows were greater than the annual outflows. The recent airport surveys revealed that return migration has declined modestly, but it still accounted for more than half of the total outflows during 1993-95 (Table 1, column 3). It appears from such statistics that Middle East migration will no longer provide a safety valve for the pressures generated by an increasing domestic labour force. Rather, reintegration of returnees, a process by which migrants after their return from overseas employment resettle themselves into the social and economic structure of their countries of origin, has been recognised as a significant part of the overall dynamics of labour migration [Amjad (1989); Kemal (1992) and Shah (1994)]. One of the important dimensions of this process is their readjustment in the local domestic market, as, in the case of Pakistan, the majority of these workers was in their mid-thirties, with 25 to 30 years of work ahead of them [Pakistan (1991); Arif (1995)].

Overseas contract workers and their families are often considered to be in a better economic and social position than non-migrant individuals and families. It is, therefore, argued that any special measures for return migrants would discriminate against those who have never had an opportunity to emigrate. Policies in the Asian

\footnotetext{
${ }^{1}$ The majority of workers returned from Kuwait were re-employed there soon after the Gulf War was over [Stahl and Appleyard (1992)].

${ }^{2}$ First between 1982 and 1987 (except 1983) and then between 1993 and 1995, the Overseas Pakistanis Foundation organised a series of airport surveys to obtain information on returning workers. Interviews, which took place at all international airports, were conducted with all workers returning from abroad in one to three selected months of the year. Migrants who were returning because of expiry of contract were considered permanent return migrants.
} 
Table 1

Annual Out Flows and Return Flows of Pakistani Workers to and from the Middle East, 1982-1995

\begin{tabular}{lccc}
\hline & Out-migrants & Return Migrants & $(2) \div(1)$ \\
Year & $(1)$ & $(2)$ & $(3)$ \\
\hline 1980 & 127,677 & 21,672 & 0.17 \\
1982 & 137,300 & 115,700 & 0.84 \\
1984 & 93,400 & 93,900 & 1.01 \\
1985 & 82,300 & 139,300 & 1.69 \\
1986 & 57,800 & 116,000 & 2.01 \\
1987 & 66,100 & 69,700 & 1.05 \\
1993 & 157,733 & 75,162 & 0.48 \\
1994 & 114,060 & 66,618 & 0.58 \\
1995 & 122,840 & 71,308 & 0.58 \\
\hline
\end{tabular}

Source: 1980 Iqbal and Khan (1981); 1982-1995 (Airport Surveys conducted by the Overseas Pakistanis Foundation).

labour-exporting countries, including Pakistan, often stress the provision of equal services to return migrants and to other members of the community [ESCAP (1986)]. Thus, the onus of responsibility for finding employment after return is mainly on individual migrant workers [Ro (1985); Lohrmann (1988)]. The overseas work experience of migrants, on the one hand, can enhance prospects of re-entering in the local labour market through increased skill levels and through the use of remittances to establish businesses and farms. On the other hand, because of discontinuity of service in local jobs, lack of recent work experience in the domestic labour market, and high reservation wages, many returning workers may face long periods of unemployment [Muschkin (1993)].

There is a considerable body of literature on labour migration from Pakistan to the Middle East, ${ }^{3}$ but little attention has been given to the issue of reintegration of return migrants in the domestic labour market. The few studies carried out on return migration have mainly attributed the high level of unemployment among return migrants to their relatively comfortable financial situation, whereby they could afford to prolong the waiting period for a suitable job [Gilani (1986); Kazi (1989) and Addleton (1992)]. The effects of other factors, such as the duration of stay abroad, pre-migration work experience, and period elapsed since return, have not been extensively examined. Moreover, in general, the previous studies have not included non-migrants in the analyses. This paper fills these gaps and examines the reintegration of Pakistani return migrants from the Middle East in the domestic

${ }^{3}$ See, for example, Gilani, Khan and Iqbal (1981); Abella and Atal (1986); Arnold and Shah (1986); Stahl (1988); Amjad (1989); Gunatilleke (1991); Addleton (1992); Shah (1994). 
labour market by: (a) comparing employment outcomes of return migrants with those of non-migrants, (b) examining employment differentials among returning workers, and (c) investigating employment preferences of unemployed returnees.

The next section conceptualises employment outcomes of Pakistani return migrants in the light of their pre-migration and overseas experiences. Data sources and methods of analysis are discussed in Section 3. Employment status of return migrants is compared with non-migrants in Section 4, followed by the reintegration pattern of return migrants in the domestic labour market. The penultimate section briefly examines the employment preferences of the unemployed return migrants. The last section then summarises the main findings and also outlines policy recommendations.

\section{CONCEPTUALISING REINTEGRATION OF RETURN MIGRANTS IN THE DOMESTIC LABOUR MARKET}

The conventional migration theories, particularly the human capital perspective, focus on the value of human capital gained through the migration experience [Muschkin (1993)]. According to this perspective, upon their return, workers serve as agents of change by applying the ideas and skills acquired abroad to establish farms, businesses, and enterprises conducive to development. Thus the employment of return migrants is likely to be positively influenced by their overseas migration experience. However, studies conducted among Asian and Mediterranean return migrants generally have not supported this argument, and have shown that many migrants face serious problems in obtaining employment after returning home [Athukorala (1990); Mahmood (1991)].

The relationship between return migrants' overseas work experience and their post-return employment outcomes is complex. In order to understand the possible effects of the migration experience on the outcomes, it is useful to discuss briefly the migrants' motives for going abroad and their aspirations upon return, particularly in terms of selection of job and income levels. The major pull factor that determines the movement of workers to foreign temporary employment is the vast difference between wages offered in the foreign labour markets and in the countries of origin. The fundamental purpose of contract migrants, generally, is to acquire as rapidly as possible a monetary reserve that will provide the basis for social mobility in their societies of origin, through buying land, building new houses, or opening shops or small businesses [Rhoades (1978); King (1986); Arif and Irfan (1997)]. To achieve their financial targets, migrants find it quite acceptable to do almost any kind of work while abroad [Taylor (1976)], and they often take lower skilled jobs offering high monetary returns [Stahl (1986)]. A large proportion of Pakistani migrants in the Middle East have been employed in unskilled jobs in which no skills are likely to be imparted to them. After years of hard work, many migrants return home with few 
new skills, and their overseas job experience may not be relevant to the needs of the local employers [Arif (1991); Arif and Shahnaz (1997)].

The high level of overseas earnings and accumulated savings are likely to raise returnees' expectations in terms of salary and working conditions. However, it is unlikely that, upon their return, migrants would be offered wages higher than those being offered to non-migrants. In this situation, Taylor (1976) argues that 'returnees cannot afford to risk the chance of reverting to their pre-migration level of income'. To increase their earnings during the post-return phase, a large proportion of returnees choose to start up their own businesses or establish farms [Arif and Irfan (1997)].

Some migrants may intend to invest in existing family enterprises into which they can readily be reintegrated after return. Rural migrants who worked on family farms before migration are likely to be quickly re-absorbed into these family enterprises after returning home [Del Campo and Garmendia (1974)]. However, selfemployment for those who have plans to start new businesses or establish new farms after their return may depend largely on their success in accumulating sufficient savings while abroad, making prudent use of these accumulated savings and having entrepreneurial training. Failure in establishing own businesses, because of the lack of either savings or relevant skills, may lead return migrants to find other employment. Nevertheless, returnees may not be willing to accept certain jobs because they place them below the higher economic and social position they have acquired through migration. Rather, they may prefer to live off their savings. In addition, local employers may not be keen to take returnees used to high wages abroad.

The adjustment of return migrants to the domestic employment situation is likely to be influenced by other factors as well. One factor is their pre-migration work experience, which could be a useful asset in re-entering the local labour market. Social connections may also play a role in securing employment after returning home [Dei (1991)]. The other important factor is time: "the length of time a migrant had been in the community to a large extent determines the level of readjustment" [Campbell et al. (1974); Miller and Neo (1997)]. It is also possible that return migrants who fail to find employment in the local labour market for a considerable period are apt either to seek some sort of compromise between their expectations and the reality that faces them, or to again seek employment abroad.

It is, however, difficult because of data constraints to examine all possible relationships among returnees' overseas work experience, their job expectations upon return, the role of social connections, and employment outcomes. For the analysis of the reintegration of Pakistani return migrants from the Middle East in the local labour market, three hypotheses are proposed: (1) that in view of the long absence of return migrants from the local labour market, lack of recent local work experience, and high reservation wages, the unemployment level among return 
migrants is higher than among non-migrants; (2) that the longer the stay of migrants in the Middle East, the less easy it is to find employment after returning home; and (3) that the longer the period since return from the Middle East, the greater the prospects of having secured employment.

\section{DATA AND METHODS OF ANALYSIS}

The present study brings together data from several sources, though it depends heavily on the 1986 ILO/ARTEP Survey of Return Migrant Households (referred to hereafter as the ILO survey). The universe for this survey was all return migrants from the Middle East in the period between January 1980 and June 1985. Return migrants were defined as those who had worked in the Middle East and had returned to Pakistan at least six months before the survey. The ILO survey covered 1327 return migrants' households in three provinces, Punjab, Sindh, and the NWFP, and in Azad Jammun and Kashmir [ILO/ARTEP (1987)]. Because of some problems in the ILO data files, 76 households were excluded from the analysis [for details, see Arif and Irfan (1997)].

The 1986 ILO survey is 11 years old, but it is the latest available national survey on return migration. The 1991 Pakistan Integrated Household Survey (PIHS) collected some useful information on workers who have returned from overseas employment. For a comparison, this survey has also been used extensively in this paper. The PIHS covered 4794 households in four provinces of the country. Each household member aged 15 years or more was asked whether he or she had ever worked abroad. The survey identified 330 males as returnees [Pakistan (1992)]. In the PIHS only six females reported to have worked abroad. Since the overwhelming majority of Pakistani migrants in the Middle East are male and the ILO survey was administered to males only, these six cases were excluded, to retain comparability between these two sources. Moreover, as noted above, the ILO survey was restricted to those migrants who had returned to Pakistan at least six months before the survey, but the period elapsed since their return must not have been more than five years. In the PIHS, for the majority of migrants, the period elapsed since their return from abroad was more than five years. In order to select a comparable group, only those migrants who had been back at least six months prior to the survey but not more than five years were selected. This restriction limits the number of returnees and only 92 records could be included in the comparison. However, in the multivariate analyses, all 330 returnees identified from the PIHS were included in one out of the three models.

One more limitation of the PIHS must be noted: it did not make a distinction among returnees with respect to their countries of employment. Therefore, the migrants selected from the PIHS might not have returned only from the Middle East. Despite these limitations, the fact is that it is the only nationally representative survey that has collected some information on return migration. It seems useful to 
include it in the analysis. The 1980 PIDE/World Bank survey of return migrant households has also been included in the analysis. ${ }^{4}$

To examine hypothesis 1 , that the level of unemployment is higher among return migrants than among non-migrants, a sample of non-migrant households was required. Data on these households were available from the 1991 PIHS and the 1980 PIDE/World Bank study, but this information was not available for the 1986 ILO survey. Therefore, a sub-sample of non-migrant households was created from the 1986-87 Household Income and Expenditure Survey (HIES). It was selected from districts where the 1986 ILO survey was conducted (For details on the sample design of the HIES and the selection of control group, [see Pakistan (1988); Arif (1995)]. The present analysis is restricted to those return migrants (or non-migrants) who were in the labour force-employed or unemployed at the time of surveys. ${ }^{5}$ In other words, persons (age 10+) who were not working and were not looking for a job at the time of the survey were excluded from the analysis. About 6 percent of return migrants covered in the 1986 ILO survey was out of the labour force at the time when the survey was conducted, while a greater proportion of return migrants identified in the 1991 PIHS, 11 percent, was not in the labour force at the time of the survey. Unemployment rate is defined as the percentage of unemployed return migrants (or non-migrants) out of the total return migrants (or non-migrants) in the labour force.

\section{EMPLOYMENT OUTCOMES: COMPARING RETURN MIGRANTS WITH NON-MIGRANTS}

It is not uncommon in return migration studies to make a comparison between return migrants and non-migrants in terms of their employment status at the time of a census or survey. ${ }^{6}$ However, there is a methodological concern. Migrants who return from overseas employment have to find a new job (or rejoin an existing family enterprise), while most non-migrants will not be seeking employment because they have existing jobs. Obviously, both the unemployment rate and the duration of job search in the case of return migrants are likely to be higher than for non-migrants. Given this reality, a comparison of return migrants' employment status should be made with that of non-migrants who were seeking employment when the migrants returned home. ${ }^{7}$ This type of comparison requires a data set, which provides Arif (1995).

${ }^{4}$ For details, on the sample design of the 1980 PIDE/World Bank surveys, see Gilani et al. (1981);

${ }^{5}$ Information on the definitions used for the employed and unemployed persons in the different surveys and in the 1981 census is reported in Appendix Table 1.

${ }^{6}$ For example, Muschkin (1993) has recently compared the employment outcomes of Puerto Rican return migrants from the USA at the time of the 1970 and 1980 censuses with the non-migrant population. Similarly, Campbell et al. (1974) compared employment status of black return migrants in the USA with black population using the 1972 census.

${ }^{7}$ Even this comparison may not be ideal because some migrants may resume their pre-migration jobs after return, but non-migrants may not have this opportunity. So one gets a bias in favour of return migrants. 
employment histories for both groups. Unfortunately, available non-migrant samples do not contain information on employment histories.

However, to make a meaningful comparison in the analysis, only those return migrants who had been back in Pakistan for 18 months or more have been compared with the non-migrant population. ${ }^{8}$ The assumption that, after spending 18 months back in the country, return migrants should be able to reach the employment levels of non-migrants is not unrealistic for several reasons. Return migrants are not newcomers who are expected to undergo a process of socialisation. They are returning to a social structure with which they are already familiar [Taylor (1976], and most of them, for example 95 percent in the ILO sample, had experience of working in the local labour market before going to the Middle East. More importantly, migrants go abroad for fixed periods of time, mainly to accumulate savings to invest in projects back home, perhaps a shop or a small business. The amount of foreign savings may not be sufficient to free migrants for long from working in the local labour market. Thus it could be expected that returnees would be able to re-adjust to the domestic employment situation in a reasonable time.

Table 2 sets out data from the 1991 PIHS, the 1986 ILO, and the 1980 PIDE/World Bank surveys: the unemployment rates among only those return migrants who had been back in Pakistan for 18 months or more. It also compares these three samples of return migrants with the 1991, 1986, and 1980 samples of non-migrants. The unemployment rates controlling for age, level of educational attainment, and type of place of residence have also been reported separately. According to the 1980 PIDE/World Bank sample, 20 percent of returnees were unemployed at the time of the survey. This percentage declined to 13 for the 1986

\begin{tabular}{|c|c|c|}
\hline \multicolumn{3}{|c|}{$\begin{array}{c}\text { Percentage of Return Migrants Employed at the Time of the ILO Survey by } \\
\text { Period Elapsed since Return from the Middle East }\end{array}$} \\
\hline Period Elapsed (Months) & Percent Employed & $(\mathrm{N})$ \\
\hline $6-11$ & 76.1 & (226) \\
\hline $12-17$ & 84.1 & (138) \\
\hline $18-23$ & 83.6 & (122) \\
\hline $24-29$ & 83.5 & (109) \\
\hline $30-35$ & 89.8 & (128) \\
\hline $36-41$ & 85.5 & (76) \\
\hline $42+$ & 88.2 & (382) \\
\hline Total & 84.5 & $(1181)$ \\
\hline
\end{tabular}


ILO sample. A further decline to 11 percent was observed in the 1991 PIHS. It seems that unemployment among returning workers has declined over time. ${ }^{9}$

Table 2

Percentages Unemployed by Migration Status of Workers According to Age, Education, and Type of Place of Residence, 1991, 1986, and 1980

\begin{tabular}{|c|c|c|c|c|c|c|}
\hline \multirow[b]{2}{*}{$\begin{array}{l}\text { Socio-demographic } \\
\text { Characteristics }\end{array}$} & \multicolumn{2}{|c|}{1991 PIHS } & \multicolumn{2}{|c|}{1986 ILO } & \multicolumn{2}{|c|}{1980 PIDE/World Bank } \\
\hline & $\begin{array}{l}\text { Return } \\
\text { Migrants }\end{array}$ & $\begin{array}{l}\text { Non- } \\
\text { migrants }\end{array}$ & $\begin{array}{l}\text { Return } \\
\text { Migrants }\end{array}$ & $\begin{array}{l}\text { Non- } \\
\text { migrants }\end{array}$ & $\begin{array}{l}\text { Return } \\
\text { Migrants }\end{array}$ & $\begin{array}{l}\text { Non- } \\
\text { migrants }\end{array}$ \\
\hline \multicolumn{7}{|l|}{ Age (Years) } \\
\hline$<30$ Years & 18.8 & 4.8 & 13.1 & 1.6 & 23.5 & 3.7 \\
\hline 30-39 Years & 7.7 & 1.6 & 11.3 & 0.8 & 8.3 & 2.2 \\
\hline$\geq 40$ Years & 8.3 & 1.6 & 14.9 & 5.5 & 27.3 & 2.4 \\
\hline \multicolumn{7}{|l|}{$\begin{array}{l}\text { Level of Educational } \\
\text { Attainment }\end{array}$} \\
\hline Illiterate & 0.0 & 2.9 & 9.6 & 4.1 & 16.1 & 0.0 \\
\hline $\begin{array}{l}\text { Pre-matriculation } \\
\text { (1-9 Years) }\end{array}$ & 12.9 & 3.0 & 13.5 & 2.6 & 15.6 & 2.9 \\
\hline $\begin{array}{l}\text { Matriculation + } \\
(10+\text { Years })\end{array}$ & 10.7 & 3.9 & 16.6 & 2.6 & 26.5 & 3.5 \\
\hline \multicolumn{7}{|l|}{ Place of Residence } \\
\hline Urban Areas & 14.8 & 4.7 & 16.2 & 4.1 & 26.8 & 2.7 \\
\hline Rural Areas & 7.7 & 2.2 & 11.1 & 2.5 & 9.8 & 2.6 \\
\hline Total Sample & 10.6 & 3.4 & 12.9 & 3.4 & 19.6 & 2.7 \\
\hline
\end{tabular}

But, Table 2 also shows that the proportions unemployed were much higher among return migrants than among non-migrants. Compared to only 3 percent of the 1980 non-migrants sample, 20 percent of the return migrant sample were unemployed. In 1986 and 1991, proportions unemployed among return migrants were, respectively, about four and three times the proportion among non-migrants. Even after controlling for age, education, and the type of place of residence, differences in the proportion unemployed between return migrants and non-migrants persisted.

To separate out the independent effect of migration status (return migrant/nonmigrant) on the employment outcomes, multivariate analyses were also carried out. The 1991 PIHS, the only data set which contains information on the migration status, was used in these analyses. Three models were estimated: model 1 , which is the full model, includes non-migrants and all returnees irrespective of the period elapsed

${ }^{9}$ It is likely that this decline was the result of an increase in the proportion of discouraged workers, returnees who because of limited job opportunities in the domestic labour market did not report themselves in the labour force (see Section 3). 
since their return from overseas employment; model 2 includes non-migrants and those returnees whose period elapsed since return was not more than five years; and model 3 includes non-migrants and those return migrants who had been back in Pakistan at least 18 months before the survey but not more than five years.

The dependent variable, employment status, takes the value one if the respondent was unemployed and zero if employed. Four explanatory variables, age, education, type of place of residence, and migration status (return migrant/nonmigrant), were entered into the above-mentioned three models. Age in completed years was included in the models. The type of place of residence takes a value of one if the respondent was residing in an urban area and zero if in a rural area. The migrant's level of educational attainment takes value of one if the respondent had 10 years or more schooling and 0 otherwise. Migration status takes value of one if the respondent was return migrant and zero if non-migrant. As the dependent variable was a binary variable, a multivariate logistic regression was used. The results (odds ratios) are presented in Table 3. A logit estimate was considered to be significant if it was at least double the associated standard error value. At the bottom of each column of the table are the relevant number of cases and Likelihood Ratio of Chi-squares $\left(\operatorname{LR} X^{2}\right)$ values.

Table 3

Logistic Regression Effects of Predictors on Employment Status 1991 (Odds Ratios)

\begin{tabular}{lccc}
\hline Variables & Model 1 & Model 2 & Model 3 \\
\hline Age & $0.98^{*}$ & $0.98^{*}$ & $0.98^{*}$ \\
$\begin{array}{l}\text { Educational Attainment } \\
\quad \text { Matriculation }\end{array}$ & - & & \\
$\quad$ Matriculation & $1.35^{*}$ & - & - \\
Place of Residence & & $1.35^{*}$ & $1.34^{*}$ \\
$\quad$ Rural & - & & \\
$\quad$ Urban & $2.20^{*}$ & - & - \\
Migration Status & & $2.20^{*}$ & $2.17^{*}$ \\
$\quad$ Non-migrants & - & & \\
$\quad$ Return Migrants & $1.80^{*}$ & - & - \\
LRX & 2684 & $3.41^{*}$ & $3.27^{*}$ \\
$\mathrm{~N}$ & 9164 & 2667 & 2627 \\
\hline
\end{tabular}

Source: Computed from the 1986 ILO survey data.

*Shows significance at 5 percent level of confidence or better. 
All explanatory variables entered into the three models turned out to be statistically significant (Table 3). Education, type of place of residence, and migration status had independent positive influences on the propensity to be unemployed, while age was negatively related with the likelihood of being unemployed. Table 3 shows that after other variables were held constant, return migrants were more likely to be unemployed than non-migrants (hypothesis 1). However, the value of odds ratios in model 1 was much lower than in models 2 and 3 , suggesting a gradual reintegration of return migrants in the domestic labour market. Despite this gradual reintegration, the fact remains that many returnees faced difficulties in their readjustment. The question is how the workers who could not find employment upon their return differ from those who were successful in their readjustment?

\section{REINTEGRATION PATTERN OF RETURN MIGRANTS IN THE DOMESTIC LABOUR MARKET}

This section focuses on return migrants and examines their reintegration pattern in the local labour market by applying logit regressions. Coding of the dependent variable, the employment status of returnees at the time of the survey, was similar to that specified in the models presented in the last section. The individual characteristics (or explanatory variables) expected to influence the employment status include age, education, type of place of residence, pre-migration work experience, duration of stay in the Middle East, occupation while abroad, savings, and the desire to re-emigrate. Operational definitions of these variables are given in Table 4.

Six separate models were estimated. Model 1, which is the full model, includes all return migrants from the ILO sample. In view of the importance of the duration of stay abroad and the period elapsed since return in finding employment (hypotheses 2 and 3), models 2 to 6 were estimated by focusing on these two variables. Accordingly, model 2 includes recent returnees, namely, those who had been back in Pakistan for less than 18 months but more than six months; earlier returnees, those who returned 18 months or more before the ILO survey, have been included in model 3. Models 4, 5, and 6 were estimated according to the duration of stay abroad. Model 4 includes short stayers, those who had stayed abroad for two years or less. Models 5 and 6 include medium stayers, those who stayed in the Middle East more than two years but less than six years, and long stayers, those who had stayed abroad for six years or more, respectively. A separate model was also estimated by using the sub-sample of the 1991 PIHS. While background characteristics of return migrants such as occupation while abroad, and savings were not available from this survey, only five explanatory variables, age, education, place

of residence, duration of stay abroad, and time elapsed since return, were entered into this model. 
Table 4

Operational Definitions of Explanatory Variables Used in Logistic Regression of Post-return Employment Status

\begin{tabular}{|c|c|}
\hline Explanatory Variables & Operational Definitions \\
\hline$\overline{\text { Age }}$ & Age in completed years is a continuous variable. \\
\hline Education & $\begin{array}{l}\text { Three levels of educational attainment were represented by two } \\
\text { dummy variables. The first variable takes the value } 1 \text { if the } \\
\text { respondent was educated to pre-matriculation level and } 0 \\
\text { otherwise. The second variable represents the matriculation or } \\
\text { above level, and was coded } 1 \text { if a respondent was in this } \\
\text { category, and } 0 \text { otherwise. The illiterate level was the reference } \\
\text { category. }\end{array}$ \\
\hline Place of Residence & $\begin{array}{l}\text { The type of place of residence, rural and urban, was entered in } \\
\text { the model as a dummy variable. The rural area was the } \\
\text { reference category. }\end{array}$ \\
\hline Pre-migration Work & $\begin{array}{l}\text { Pre-migration work status took the value } 1 \text { if the respondent } \\
\text { was working before migration and zero if he was not working. }\end{array}$ \\
\hline Occupation While Abroad & $\begin{array}{l}\text { Two of the three major occupations while abroad groups } \\
\text { production (skilled and unskilled) and other (service, } \\
\text { agriculture, business, and others) workers. These were entered } \\
\text { in the model as dummy variables. The first variable took the } \\
\text { value } 1 \text { if the respondent was a production worker while abroad } \\
\text { and } 0 \text { otherwise. The second variable represented other } \\
\text { workers, and was coded } 1 \text { if a respondent was in this category } \\
\text { and } 0 \text { otherwise. The clerical/professional category was the } \\
\text { reference category. }\end{array}$ \\
\hline Duration of Stay Abroad & $\begin{array}{l}\text { Three categories of duration of stay abroad, short stayers, } \\
\text { medium stayers, and long stayers, were represented by two } \\
\text { dummy variables. The first variable represented medium } \\
\text { stayers, and was coded } 1 \text { if a respondent was a medium stayer } \\
\text { and } 0 \text { otherwise. The second variable represented long stayers, } \\
\text { and was coded } 1 \text { if a respondent was in this category and } 0 \\
\text { otherwise. The short stayers category was the reference } \\
\text { category. }\end{array}$ \\
\hline Savings & $\begin{array}{l}\text { Total amount of savings at the time of return in rupees }(000) \text { is } \\
\text { a continuous variable. }\end{array}$ \\
\hline Desire to Re-emigrate & $\begin{array}{l}\text { Desire to re-emigrate is a dichotomous variable that took the } \\
\text { value } 1 \text { if the respondent had a desire to re-emigrate at the time } \\
\text { of the survey and } 0 \text { if he had no desire to re-emigrate. }\end{array}$ \\
\hline Return Status & $\begin{array}{l}\text { Return status is a dichotomous variable that took the value } 1 \text { if } \\
\text { the respondent had been back for more than } 18 \text { months } \\
\text { preceding the survey and } 0 \text { if he had been back for } 18 \text { months } \\
\text { or less. }\end{array}$ \\
\hline
\end{tabular}


Results of the models estimated from the ILO and the PIHS samples are presented in Tables 5 and 6 . In model 1 , five variables turned out to be statistically significant. Three variables, length of stay abroad, occupation while abroad, and having a desire to re-emigrate, had independent positive influences on the propensity to be unemployed, while the other two variables, pre-migration employment status and period elapsed since return, were negatively related with the likelihood of being unemployed (Table 5). The signs were consistent with the hypotheses. The negative relationship between the period elapsed since return and the likelihood of being unemployed indicates that re-employment of return migrants was time-dependent, and that with the passage of time returnees were likely to be re-integrated into the local labour market. The positive relationship between the length of stay abroad and unemployment indicates that long absence from the local labour market could be a hindrance in finding employment. Figure 1 shows that even after controlling for the length of time elapsed since return, there were major differences in unemployment rates across different categories of migrants' durations of stay abroad. There might be a strong inclination among long stayers to start an independent trade or business to maintain the standard achieved during overseas migration. As Pasha and Altaf (1987) reported from the results of a survey of Pakistani migrants in Saudi Arabia, workers when asked the level of income in Pakistan that would induce them to return home generally mentioned an income figure roughly two to two-and-half times what they were being paid in Pakistan at the time of migration. However, it is unlikely that they would be offered wages higher than those offered to non-migrants. As noted earlier, to increase their earnings upon return, they may choose independent work which is 'very slow to materialise' [Amjad (1989)].

Occupations while abroad also had an independent effect on the propensity to be unemployed (model 1, Table 5). Migrants who were professional and clerical workers during Middle East employment were less likely to have found employment in the local labour market after returning home than those who were production, service, business or agriculture workers while abroad. Professional and clerical workers were likely to find employment in the formal sector; that could have made finding a job hard. With respect to the pre-migration phase, having worked had a significant negative effect on post-return likelihood of being unemployed. Migrants who were working before migration were about three times as likely to have found employment after returning as those who were not working before going abroad. This suggests that pre-migration work experience in the local labour market was useful in finding employment after return. It is also likely that many migrants returned to their previous jobs, particularly in the agriculture sector. As expected, having a desire to re-emigrate was positively associated with the propensity to be unemployed.

The results of the model estimated from the 1991 PIHS data set (Table 6) are supportive of the results obtained from model 1 based on the 1986 ILO survey 
Table 5

Logistic Regression Effects of Predictors on Post-return Employment Status of Migrants, 1986 (Odds Ratios)

\begin{tabular}{|c|c|c|c|c|c|c|}
\hline Variable & Model 1 & Model 2 & Model 3 & Model 4 & Model 5 & Model 6 \\
\hline Age at the Time of Return & 1.00 & 1.00 & 1.00 & 1.00 & 0.99 & 1.00 \\
\hline \multicolumn{7}{|l|}{ Educational Attainment } \\
\hline Illiterate & - & - & - & - & - & - \\
\hline Pre-matriculation & 1.18 & 1.27 & 1.04 & 1.47 & 1.14 & 1.17 \\
\hline Matriculation + & 1.46 & 1.09 & $2.37 *$ & 1.83 & 1.38 & 1.01 \\
\hline \multicolumn{7}{|l|}{ Type of Place of Residence } \\
\hline Rural & - & - & - & - & - & - \\
\hline Urban & 1.32 & 1.31 & 1.44 & 1.04 & 1.37 & $2.11^{*}$ \\
\hline \multicolumn{7}{|l|}{ Pre-migration Employment } \\
\hline \multicolumn{7}{|l|}{ Status } \\
\hline Not Working & - & - & - & - & - & - \\
\hline Working & $0.41^{*}$ & $0.36^{*}$ & 0.45 & $0.31^{*}$ & 0.52 & 0.38 \\
\hline \multicolumn{7}{|l|}{ Occupation While Abroad } \\
\hline \multicolumn{7}{|l|}{ Production/Service/ } \\
\hline Agriculture/Business & - & - & - & - & - & - \\
\hline Professional/Clerical & $2.57^{*}$ & $3.27^{*}$ & 1.83 & $8.80^{*}$ & $2.25^{*}$ & 1.71 \\
\hline \multicolumn{7}{|l|}{ Length of Stay Abroad } \\
\hline Short Stayers & - & - & - & - & - & - \\
\hline Medium Stayers & 1.28 & 1.25 & 1.30 & - & - & - \\
\hline Long Stayers & $1.79^{*}$ & $2.35^{*}$ & 1.16 & - & - & - \\
\hline Savings & 1.00 & 1.00 & $0.99 *$ & 1.00 & 1.00 & 1.00 \\
\hline \multicolumn{7}{|l|}{ Desire to Re-emigrate } \\
\hline No & - & - & - & - & - & - \\
\hline Yes & $2.65^{*}$ & $2.10^{*}$ & $4.37 *$ & 1.95 & $2.25^{*}$ & $5.93^{*}$ \\
\hline \multicolumn{7}{|l|}{ Return Status } \\
\hline Recent Returnees & - & - & - & - & - & - \\
\hline Earlier Returnees & $0.59 *$ & - & - & 0.62 & $0.47^{*}$ & 0.74 \\
\hline $\mathrm{LR} X^{2}$ & 913 & 579 & 319 & 246 & 438 & 220 \\
\hline Number of Cases & 1181 & 817 & 364 & 400 & 540 & 241 \\
\hline
\end{tabular}

Source: Computed from the 1986 ILO survey data.

Note: Model 1 is a full model which includes the total ILO sample (excluding those who were not in the labour force); Model 2 includes only earlier returnees; Model 3 refers to recent returnees; short, medium, and long stayers are included in models 4,5 , and 6 , respectively.

*Shows significance at 5 percent level of confidence or better. 
Table 6

Logistic Regression Effects of Predictors on Post-return Employment Status of Migrants, 1991 (Odds Ratios)

\begin{tabular}{|c|c|}
\hline Variable & Odds Ratios \\
\hline Age (Years) & 1.00 \\
\hline \multicolumn{2}{|c|}{ Educational Attainment } \\
\hline$<$ Matriculation & - \\
\hline$\geq$ Matriculation & 1.40 \\
\hline \multicolumn{2}{|l|}{ Place of Residence } \\
\hline Rural & - \\
\hline Urban & 1.30 \\
\hline \multicolumn{2}{|c|}{ Length of Stay Abroad } \\
\hline Short Stayers & - \\
\hline Medium Stayers & 5.63* \\
\hline Long Stayers & 2.80 \\
\hline \multicolumn{2}{|l|}{ Return Status } \\
\hline Recent Returnees & - \\
\hline Earlier Returnees & $0.30 *$ \\
\hline $\mathrm{LR} X^{2}$ & 68 \\
\hline Number of Cases & 92 \\
\hline
\end{tabular}

Source: Computed from the 1991 PIHS data.

*Shows significance at 10 percent level of confidence or better.

(\%) 15

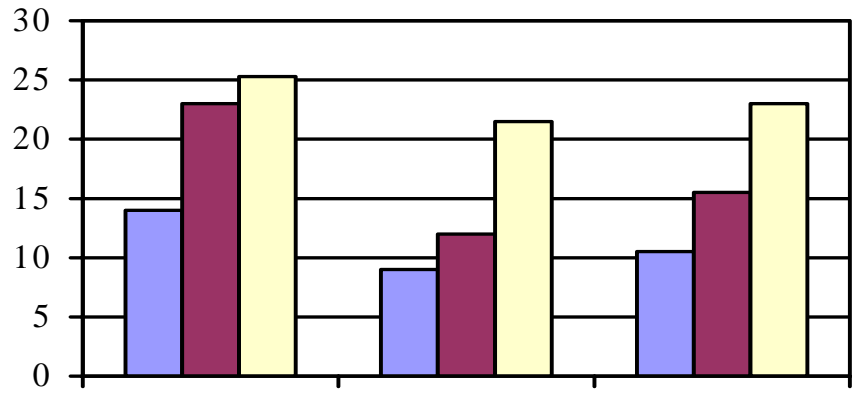

Recent

Earlier

Total Sample

Returnees Returnees

Period Elapsed Since Return

$\square$ Short Stayers

$\square$ Medium Stayers

$\square$ Long Stayers

Fig. 1. Percentage Unemployed by Duration of Stay Abroad Controlling for Period Elapsed Since Return. 
(Table 5). The length of stay abroad had a significant positive effect on the likelihood of being unemployed, and the period elapsed since return was also significant and negatively associated with the propensity to be unemployed (hypotheses 2 and 3). Age and education, as in model 1, did not turn out to be statistically significant.

The results of models 2 and 3, which examine the likelihood of being unemployed, of earlier and recent returnees respectively, are also presented in Table 5. All explanatory variables used in the full model (model 1) have been repeated in models 2 and 3, except the period elapsed since return. As with model 1, premigration work status, occupation while abroad, length of stay abroad, and having a desire to re-emigrate were statistically significant in model 2 (earlier returnees). In model 3 (recent returnees), education and having a desire to re-emigrate were statistically significant, and had positive effects on the likelihood of being unemployed. The effect of savings on this likelihood was significant and negative: each additional rupee of savings slightly decreased the likelihood that the respondent was not employed. Arif (1995) estimated that short stayers had directed proportionately more of their remittances to savings (and not much to investment) than medium and long stayers. Thus, having savings may in a perverse way be an indicator of the need to resume local employment as soon as possible-a migrant may tend to have reasonable savings when he does not have enough of them to convert them into investments.

The results of the models 4,5 , and 6 , which examine propensities to be unemployed according to migrants' length of stay abroad (short stayers, medium stayers, and long stayers respectively), are also presented in Table 5. All independent variables used in the full model (model 1) were also included in these three models, except for the duration of stay abroad. In model 4 (short stayers), only three variables, pre-migration employment status, occupation while abroad, and having a desire to re-emigrate, turned out to be statistically significant. The last two variables and the period elapsed since return were significant in model 5 (medium stayers); while in model 6, place of residence (residing in urban areas) and desire to reemigrate had significant effects on post-return employment outcomes.

It appears from the results of models 4, 5, and 6 that the re-employment experience of return migrants differs widely across the three categories of duration of stay abroad. For example, model 4 is the only model where having the desire to reemigrate did not turn out to be statistically significant, suggesting that for short stayers overseas employment in general was not satisfactory. Short stayers were likely to have returned home because of family or personal health problems. It is also possible that most of them were illegal migrants, who were forced by the authorities of the host countries to return home. If they had spent considerable amounts of money to obtain overseas employment and had generally been unable to accumulate savings, it would have been hard for them to finance re-emigration. Re-employment 
of short stayers mainly depended on the pre-migration employment status and occupation while abroad (model 4). The statistical significance of return status for medium stayers suggests that their re-absorption was time-dependent. The longer the period elapsed since their return, the more likely they were to be employed. However, the re-employment of long stayers, who were likely to be relatively more educated and mainly drawn from urban areas, was at a crossroads. Having a desire to re-emigrate rather than accept wages offered in the domestic labour market appears for them to be a hindrance to re-adjustment. In short, reintegration of return migrants in the domestic labour market was influenced by several factors, particularly their pre-migration work experience, duration of stay abroad, occupation while abroad, period elapsed since their return, and desire to re-emigrate.

\section{EMPLOYMENT PREFERENCES OF THE UNEMPLOYED RETURN MIGRANTS}

Now the question is: What types of job were the unemployed returnees looking for, and how did these jobs differ from those held by the employed return migrants? Table 7 compares the nature of the jobs desired by the ILO unemployed sample with the jobs (occupations) held by the employed sample. It also sets out data on pre-migration and during-migration occupations of both employed and unemployed returnees. Occupational composition of the total employed population of Pakistan (age 10+) in 1986-87 is also given in Table 7. Three major points can be drawn from this table.

First, in terms of both their pre-migration and during-migration occupational composition, the unemployed returnees differ substantially from the employed sample. About 14 percent of the former were professional/clerical workers before going to the Middle East, while in the case of the latter this percentage was only 7 . Similarly, compared to only 8 percent of the unemployed sample, more than onefifth of the employed sample was engaged in the agriculture sector before going to the Middle East. The unemployed returnees largely retained their pre-migration occupational status during their overseas employment. But, many of the employed returnees changed their pre-migration occupations and switched to production sector employment while in the Middle East [For details on occupational change, see Arif and Irfan (1997)].

Second, the nature of work the unemployed migrants were looking for after their return was not very much different from the jobs they had held before migration and during their employment in the Middle East. Only a small proportion of the unemployed returnees desired to become self-employed, while the majority of the employed sample was engaged in independent work. Third, the nature of jobs desired by the unemployed returnees was not consonant with the occupational structure of the employed population of the country, influenced heavily by employment in the agriculture sector (Table 7, last column). 
Table 7

Percentage Distributions of Return Migrants by Pre-migration, During Migration and Post-return Occupation, 1986

\begin{tabular}{|c|c|c|c|c|c|c|c|}
\hline \multirow[b]{2}{*}{$\begin{array}{l}\text { Occupation/ } \\
\text { Work Status }\end{array}$} & \multicolumn{3}{|c|}{$\begin{array}{l}\text { Returnees Employed } \\
\text { at the Time of Survey }\end{array}$} & \multicolumn{3}{|c|}{$\begin{array}{l}\text { Returnees Unemployed } \\
\text { at the Time of Survey }\end{array}$} & \multirow[b]{2}{*}{$\begin{array}{l}\text { Employed } \\
\text { Population } \\
\text { of Pakistan }\end{array}$} \\
\hline & $\begin{array}{c}\text { Pre- } \\
\text { migration }\end{array}$ & $\begin{array}{c}\text { During } \\
\text { Migration }\end{array}$ & $\begin{array}{c}\text { After } \\
\text { Return } \\
\text { Migration }\end{array}$ & $\begin{array}{c}\text { Pre- } \\
\text { migration }\end{array}$ & $\begin{array}{c}\text { During } \\
\text { Migration }\end{array}$ & $\begin{array}{c}\text { After } \\
\text { Return Job } \\
\text { Desired }\end{array}$ & \\
\hline Professional/Clerical & 6.6 & 5.6 & 4.5 & 14.9 & 17.7 & 14.9 & 8.5 \\
\hline Business & 10.7 & 1.7 & 31.8 & 7.7 & 1.7 & 8.3 & 11.3 \\
\hline Agriculture & 21.0 & 1.4 & 27.2 & 8.3 & 0.0 & 0.0 & 48.8 \\
\hline Service & 10.9 & 17.1 & 9.1 & 14.9 & 19.3 & 22.1 & 4.5 \\
\hline Production & 45.0 & 74.2 & 27.4 & 40.4 & 61.3 & 54.7 & 26.9 \\
\hline Not Working & 5.8 & 0.0 & 0.0 & 13.8 & 0.0 & 0.0 & 0.0 \\
\hline All & 100.0 & 100.0 & 100.0 & 100.0 & 100.0 & 100.0 & 100.0 \\
\hline
\end{tabular}

Source: Computed from the 1986 ILO survey; Pakistan Labour Force Survey 1986-87.

These relationships indicate that unemployed returnees who retained their premigration occupations during their employment in the Middle East desire to maintain those occupations after return. Lack of recent experience of local market and probably high reservation wages seem to be major obstacles to secure desired employment. But the possibility that the unemployed returnees could not save abroad sufficient amounts of money to become self-employed cannot be ruled out.

Finally, a discussion on reintegration of return migrants in the domestic labour market would be incomplete without examining whether those who were successful in finding employment were satisfied with their jobs. It is not easy to know precisely the answer to this question. The one simple way is to administer a direct question to returnees during a survey about their job satisfaction [Taylor (1976); Gilani (1986)]. This approach was adopted in the 1986 ILO survey, with return migrants being asked: Are you satisfied with your current job? In view of the importance of earnings, returnees in the ILO sample were also asked: Is your income from your present job sufficient to meet your household expenditure? The responses to these two questions were used to assess levels of job satisfaction after return.

Results are presented in Table 8. About 60 percent of employed return migrants reported satisfaction with their post-migration jobs. There was a positive relationship between age and proportion satisfied with present job, but education showed a negative association with job satisfaction. In general, rural migrants appear to be more satisfied with their jobs than their urban counterparts. The relationship between duration of stay abroad and job satisfaction was not clear. Returnees in the business category were slightly more satisfied with their jobs than those in other categories of occupation. Even after age, education, duration of stay abroad, and place of residence were controlled for, this difference generally remained. It seems from Table 8 that reference groups with whom returnees were likely to compare 
Table 8

Percentages of Return Migrants who Were Satisfied with Their Post-migration Occupations and who Reported that Their Incomes Were Sufficient to Meet Household Requirements, by Geographical Location, Education, and Length of Stay Abroad

\begin{tabular}{|c|c|c|c|c|c|c|c|c|c|c|}
\hline \multirow[b]{2}{*}{$\begin{array}{l}\text { Age, Geographical Location, } \\
\text { Education, Duration of Stay }\end{array}$} & \multicolumn{2}{|c|}{ Professional/Clerical } & \multicolumn{2}{|c|}{ Agriculture } & \multicolumn{2}{|c|}{ Business } & \multicolumn{2}{|c|}{ Production/Service } & \multicolumn{2}{|c|}{ Total Employed } \\
\hline & $\begin{array}{l}\text { Satisfied } \\
\text { with Job }\end{array}$ & $\begin{array}{c}\text { Income } \\
\text { Sufficient }\end{array}$ & $\begin{array}{l}\text { Satisfied } \\
\text { with Job } \\
\end{array}$ & $\begin{array}{c}\text { Income } \\
\text { Sufficient }\end{array}$ & $\begin{array}{l}\text { Satisfied } \\
\text { with Job } \\
\end{array}$ & $\begin{array}{c}\text { Income } \\
\text { Sufficient }\end{array}$ & $\begin{array}{l}\text { Satisfied } \\
\text { with Job }\end{array}$ & $\begin{array}{c}\text { Income } \\
\text { Sufficient }\end{array}$ & $\begin{array}{l}\text { Satisfied } \\
\text { with Job } \\
\end{array}$ & $\begin{array}{c}\text { Income } \\
\text { Sufficient }\end{array}$ \\
\hline \multicolumn{11}{|l|}{ Age (Years) } \\
\hline$<30$ Years & 71.4 & 57.1 & 55.6 & 44.4 & 66.7 & 52.6 & 50.0 & 44.2 & 57.8 & 47.6 \\
\hline 30-39 Years & 56.0 & 36.0 & 54.9 & 51.6 & 66.4 & 57.9 & 58.3 & 54.2 & 59.8 & 53.4 \\
\hline $40+$ Years & 33.3 & 50.0 & 59.3 & 48.4 & 56.4 & 49.1 & 75.7 & 62.2 & 63.4 & 57.4 \\
\hline \multicolumn{11}{|l|}{ Place of Residence } \\
\hline Urban Areas & 47.8 & 34.8 & 66.7 & 33.3 & 59.7 & 45.1 & 54.9 & 40.7 & 43.1 & 41.9 \\
\hline Rural Areas & 68.2 & 54.5 & 56.0 & 52.1 & 69.0 & 60.9 & 60.3 & 59.3 & 61.2 & 56.8 \\
\hline \multicolumn{11}{|c|}{ Level of Educational Attainment } \\
\hline Illiterate & 0.0 & 0.0 & 58.4 & 50.4 & 69.2 & 60.3 & 59.7 & 53.9 & 61.2 & 53.9 \\
\hline Pre-matriculation & 75.0 & 50.0 & 52.0 & 57.1 & 64.2 & 54.7 & 58.1 & 52.7 & 59.0 & 54.4 \\
\hline Matriculation + & 56.1 & 43.9 & 61.1 & 38.9 & 62.0 & 46.7 & 51.1 & 35.6 & 58.4 & 42.5 \\
\hline \multicolumn{11}{|l|}{ Duration of Stay Abroad } \\
\hline Short Stayers & 50.0 & 28.6 & 59.8 & 52.3 & 67.9 & 58.0 & 55.1 & 52.6 & 59.2 & 52.8 \\
\hline Medium Stayers & 70.8 & 62.5 & 52.3 & 48.6 & 65.6 & 53.0 & 60.0 & 51.4 & 60.6 & 51.9 \\
\hline Long Stayers & 28.6 & 14.3 & 57.9 & 54.4 & 60.5 & 51.2 & 60.0 & 42.9 & 58.4 & 49.2 \\
\hline Total Employed & 57.8 & 55.6 & 56.5 & 51.3 & 64.8 & 53.8 & 57.9 & 51.1 & 59.7 & 44.4 \\
\hline
\end{tabular}

Source: Computed from the 1986 ILO survey data. 
themselves affected their job satisfaction. While educated returnees were relatively dissatisfied with their jobs, it is likely that they compared themselves with those who were working in better positions, probably in the public sector.

Table 8 also reveals that 52 percent of employed respondents in the ILO sample indicated that their earnings were adequate for their requirements. ${ }^{10}$ There was not an appreciable difference among occupational categories of return migrants with respect to adequacy of post-migration income. In the rural areas, more than 60 percent of return migrants reported that their incomes were sufficient, while in the urban areas, only 43 percent were meeting their households' requirements from their earnings. The proportion of workers with matriculation or better levels of education who indicated that their incomes were sufficient was lower than equivalent proportions for illiterate and less educated returnees. It is unlikely that the earnings of educated return migrants were lower than the earnings of illiterate or less educated workers. However, it is likely that the standard of living of educated return migrants was higher than that of uneducated or less educated workers, and that post-migration incomes in the case of the former could less often meet their requirements. Similarly, the cost of living was likely to be higher in urban than in rural areas. The incomes of many urban workers were not sufficient to cover this cost. Unlike education, there was a positive relationship between age and the proportion who were earning enough money. This positive relationship reflects the fact that younger returnees, who were at early stages of their careers, were less satisfied with their earnings than older migrants.

It appears from the above discussion that a considerable proportion of returnees was well-adjusted in their work spheres, although many still wished to see improvements in their jobs. The picture of the employed return migrants that has emerged from the present analysis seems to be more favourable than the one drawn by Gilani (1986), who argued that Pakistani returnees from the Middle East were generally not satisfied with what they had achieved from migration. However, it is in accordance with the findings of Khan (1991), who shows that an overwhelming majority of returnees were well-adjusted and regarded their overseas experience as very beneficial.

\section{CONCLUSION AND POLICY IMPLICATIONS}

This study first compared unemployment rates among Pakistani migrants returned from the Middle East with those among non-migrants and then examined the reintegration patterns of returnees in the domestic labour market. The study

${ }^{10}$ It is important to note that this percentage was about eight percent lower than the proportion satisfied with their jobs. This suggests that the job satisfaction of returnees does not necessarily mean that their earnings were sufficient. When respondents who reported that their incomes were insufficient were asked how the deficit was met, about half of them did not cite any source, and 28 percent responded that they were using accumulated savings. 
utilised three data sets: the 1980 PIDE/World Bank Survey of Return Migrant (and Non-migrant) Households, the 1986 ILO/ARTEP Survey of Return Migrant Households, and the 1991 Pakistan Integrated Household Survey. The results show that unemployment rates were much higher among return migrants than among nonmigrants. This difference narrowed with the passage of time. But, even among those who had returned to Pakistan at least 18 months prior to the surveys, more than 10 percent of workers were unemployed. The multivariate analysis further showed that returnees, irrespective of period elapsed since their return, were more likely to be unemployed than non-migrants. With respect to the reintegration pattern of return migrants, the study revealed that variables indicating their human capital, such as occupation and pre-migration and during-migration work experience, appears to have greater influence on their post-return adjustment than variables related to economic positions, such as savings. The results also show that the types of job the unemployed returnees were looking for differed substantially from those held by the employed return migrants. The majority of the latter was self-employed, but only a small proportion of the former desired to engage in independent work. The possibility is that the unemployed returnees could not save from overseas employment such amounts of money as would be sufficient to become selfemployed.

Thus assuming simply that migrants are in a relatively advantageous economic position cannot ignore the issue of reabsorption of unemployed return migrants. Returnees unemployed for long periods of time must be identified as a special target group to be absorbed into the domestic labour market. Provision of credit for self-employment seems to be the right way to readjust these workers. The Government of Pakistan has already introduced credit schemes to promote selfemployment, particularly among the educated unemployed. Unemployed returnees can be included in these schemes, and agencies concerned with overseas migration, such as the Overseas Pakistanis Foundation, should take the responsibility for providing unemployed returnees with information and assistance that will aid their readjustment.

Moreover, some financial programmes and credit schemes exist at present for persons who want to make investments in Pakistan. But there are no such programmes or schemes targeting migrants returning from overseas employment. In some other countries, particularly Turkey, banks have some financial schemes for such returnees. These schemes require certain conditions to be fulfilled. The potential returnees, if they wish to take a low-interest loan, are usually required to deposit a certain sum of money (in foreign currency) in the bank at least one year before returning to Turkey. For example, the Turkish People's Bank provides credit facilities to the returnees for the setting up of small- and medium-scale firms. This bank helps to finance investments in integrated small-scale industrial centres in many Turkish towns. The bank also provides the returnees with low-interest loans for 
industrial plants and equipment. Similarly, the Agricultural Bank in Turkey assists individuals in farming, with the help of loans from a special fund. In order to be eligible for these loans, the returnees, as a rule, have to deposit up to 20 percent of the total cost one year in advance. The bank is also active in the establishment of farming co-operatives, as well as in cattle-breeding, and in modernising farm equipment, machinery, and other agricultural projects.

Following the experience of Turkey, commercial banks and the Agricultural Development Bank of Pakistan may introduce some schemes targeting migrants returning from overseas employment, say by giving them incentives to have a foreign currency account in the banks during their stay abroad. An information system also needs to be developed for easy access to these programmes for overseas workers. 
Appendix Table 1

Definitions of Pakistani Labour Force Used in Different Surveys and the 1981 Population Census

\begin{tabular}{|c|c|c|c|}
\hline Surveys/Censuses & Labour Force & Employed & Unemployed \\
\hline $\begin{array}{l}\text { Pakistan } \\
\text { Labour } \\
\text { Force } \\
\text { Survey }\end{array}$ & $\begin{array}{l}\text { All persons } 10 \text { years of age and } \\
\text { older who were employed or } \\
\text { unemployed during the reference } \\
\text { period. }\end{array}$ & $\begin{array}{l}\text { All persons } 10 \text { years of age and above who } \\
\text { worked for pay or profit in cash or kind } \\
\text { (including unpaid family helper) for at least } \\
\text { one hour during the week preceding the } \\
\text { survey. }\end{array}$ & $\begin{array}{l}\text { All persons } 10 \text { years of age and above } \\
\text { who did not work but were looking for } \\
\text { work during the week preceding the } \\
\text { survey. }\end{array}$ \\
\hline $\begin{array}{l}1981 \\
\text { Population } \\
\text { Census }\end{array}$ & Same as above & $\begin{array}{l}\text { All persons } 10 \text { years of age and above who } \\
\text { were usually working (self-employed, } \\
\text { employee, employer, unpaid family helper). }\end{array}$ & $\begin{array}{l}\text { All persons } 10 \text { years of age and above } \\
\text { who were not working usually but } \\
\text { were looking for work. }\end{array}$ \\
\hline $\begin{array}{l}\text { Household } \\
\text { Income } \\
\text { Expenditure } \\
\text { Survey }\end{array}$ & Not defined. & $\begin{array}{l}\text { All persons aged } 10 \text { years and above who } \\
\text { worked most of the week preceding } \\
\text { the survey (include unpaid family workers). }\end{array}$ & $\begin{array}{l}\text { All persons aged } 10 \text { years and above } \\
\text { who did not work most of the } \\
\text { week preceding the survey and were } \\
\text { looking for work. }\end{array}$ \\
\hline $\begin{array}{l}1991 \\
\text { PIHS }\end{array}$ & Not defined. & $\begin{array}{l}\text { All persons aged } 10 \text { years and above who } \\
\text { worked most of the week preceding } \\
\text { the survey (include unpaid family workers). }\end{array}$ & $\begin{array}{l}\text { All persons aged } 10 \text { years and above } \\
\text { who did not work most of the } \\
\text { week preceding the survey and were } \\
\text { looking for work. }\end{array}$ \\
\hline $\begin{array}{l}1986 \\
\text { ILO } \\
\text { Survey }\end{array}$ & Not defined. & $\begin{array}{l}\text { Migrants who returned from the Middle East } \\
\text { six months before the survey and were } \\
\text { working full-time or part-time during the } \\
\text { month preceding the survey. }\end{array}$ & $\begin{array}{l}\text { Migrants who returned from the } \\
\text { Middle East six months before the } \\
\text { survey and were not working but were } \\
\text { looking for work during the month } \\
\text { preceding the survey. }\end{array}$ \\
\hline
\end{tabular}

Source: Pakistan (1984:xiv); Pakistan (1990:vii); Gilani, Khan and Iqbal (1981); ILO-ARTEP (1987)

Note: In the 1990-91 Labour Force Survey, the definition of the unemployed component of the labour force was changed. According to the new definition, all persons 10 years of age and older who (a) were not in paid employment or self-employment, (b) were available for paid employment or self-employment, and (c) had taken specific steps in a recent period to seek employment or self-employment and yet were unemployed during the reference period (one week preceding the survey). However, the Survey also provides data according to the old definition [Pakistan (1992a)]. 


\section{REFERENCES}

Abella, I. M., and Y. Atal (1986) Middle East Interlude: Asian Workers Abroad. Bangkok: UNESCO Regional Office. 109-174.

Addleton, J. S. (1992) Undermining the Centre: The Gulf Migration and Pakistan. Karachi: Oxford University Press.

Akhtar, R. (1997) Reabsorption of the Return Migrants in Pakistan. Paper presented and Regional Workshop on Return Migration and Development in South Asia Organised by Department of Economics Quaid-i-Azam University and Department of Agricultural and Social Sciences in the Tropics, University of Hohenheim, Germany, Islamabad. May 26-28.

Amjad, R (ed) (1989) To the Gulf and Back: Studies on the Economic Impact of Asian Labour Migration. New Delhi: UNDP/ILO-ARTEP.

Arif, G. M. (1991) Emigration, Skill Acquisition and Employment Choices of Return Migrants: The Experience of Pakistan. MA Research Paper, Graduate Studies in Demography, Australian National University, Canberra.

Arif, G. M. (1995) International Contract Labour Migration and Reintegration of Return Migrants: the Experience of Pakistan. Unpublished Ph.D. thesis. The Australian National University, Canberra.

Arif, G. M., and L. Shahnaz (1997) Emigration and Skill Acquisition: An Evidence from the Two Surveys of Pakistani Migrants Returned from the Middle East. Paper presented at the Regional Workshop on Return Migration and Long-term Economic Development in South Asia, organised by University of Hohenheim, (Germany) and Quaid-i-Azam University (Pakistan), held in Islamabad. May 2629.

Arif, G. M., and M. Irfan (1997) Return Migration and Occupational Change: The Case of Pakistani Migrants Returned from the Middle East. The Pakistan Development Review 36:1 1-37.

Arnold, F., and N. M. Shah (1986) Asian Labour Migration: Pipeline to the Middle East. Boulder, Colorado and London: Westview Press.

Athukorala, P. (1990) International Contract Migration and the Reintegration of Return Migrants: The Experience of Sri Lanka. International Migration Review 24:2 323-345.

Campbell, R. R., D. M. Johnson, and G. Strangler (1974) Return Migration of Black People to the South. Rural Sociology 39:4 514-528.

Dei, G. J. S. (1991) The Re-integration and Rehabilitation of Migrant Workers into Local Domestic Economy: Lessons for Endogenous Development. Human Organisation 50:4 327-336.

Del Campo, S., and J. A. Garmendia (1974) The Return of Emigrants. In G. Tapinos (ed) International Migration: Proceedings of a Seminar on Demographic Research in Relation to International Migration. Held in Buenos Aires, Argentine, 1-11 March. 210-221, Paris: CICRED. 
Economic and Social Commission for Asia and the Pacific (ESCAP) (1986) Recent Trends in International Labour Migration in Asia and Measures to Reintegrate Returning Workers. Round Table on International Labour Migration in the Philippines and South East Asia Manila, 8-11 December.

Gilani, I. (1986) Pakistan. In I. M. Abella and Y. Atal (eds) Middle East Interlude: Asian Workers Abroad. Bangkok: UNESCO Regional Office. 109-174.

Gilani, I., F. Khan, and M. Iqbal (1981) Labour Migration from Pakistan to the Middle East and Its Impact on the Domestic Economy (Sample Design). Pakistan Institute of Development Economics, Islamabad. (Research Report Nos. 126, 127, 128.)

Gunatilleke, G. (ed) (1991) Migration to the Arab World: Experience of Returning Migrants. Tokyo: United Nations University Press.

ILO/ARTEP (1987) Impact of Out and Return Migration on Domestic Employment in Pakistan, Volume IV: Survey of Return Migrants Sample Design and Field Work. New Delhi: ILO/ARTEP.

Iqbal, M., and M. F. Khan (1981) Economic Implications of the Return Flow of Immigrants from the Middle East: A Preliminary Study. Pakistan Institute of Development Economics, Islamabad. (Research Report No. 132.)

Kazi, S. (1989) Domestic Impact of Overseas Migration; Pakistan. In To the Gulf and Back: Studies on the Economic Impact of Asian Labour Migration. New Delhi: UNDP/ILO-ARTEP. 167-196.

Kemal, A. R. (1992) Identification of Potential Sectors and Areas for Gainful Absorption of Return Migrants. In Returning Migrants and their Re-integration in the Economy. Islamabad: Pakistan Manpower Institute. 36-50.

Khan, M. F. (1991) Migrant Workers to the Arab World: The Experience of Pakistan. In G. Gunatilleke (ed) Migration to the Arab World: Experience of Returning Migrants. Tokyo: United Nations University Press. 195-223.

King, R. (1986) Return Migration and Regional Economic Development: An Overview. In R. King (ed) Return Migration and Regional Economic Problems. London: Croom Helm.

Lohrmann, R. (1988) Measures to Facilitate the Re-integration of Returning Migrant Workers: International Experience. International Migration 26:2 187-197.

Mahmood, R. A. (1991) Bangladeshi Returned Migrants from the Middle East: Process, Achievement, and Adjustment. In G. Gunatilleke (ed) Migration to the Arab World: Experience of Returning Migrants. Tokyo: United Nations University Press. 238-289.

Miller, P. W., and L. M. Neo (1997) Immigrant Unemployment: The Australian Experience. International Migration 35:2 155-186.

Muschkin, C. G. (1993) Consequences of Return Migrant Status for Employment in Puerto Rico. International Migration Review 27:1 79-102. 
Pakistan, Government of (1984) The 1981 Census Report of Pakistan. Islamabad: Population Census Organisation.

Pakistan, Government of (1988) Household Income Expenditure Survey 1986-87. Islamabad: Federal Bureau of Statistics, Statistics Division.

Pakistan, Government of (1988a) Labour Force Survey 1986-87. Islamabad: Federal Bureau of Statistics, Statistics Division.

Pakistan, Government of (1990) Pakistan Statistical Year Book 1990. Islamabad: Federal Bureau of Statistics.

Pakistan, Government of (1991) Report of the National Manpower Commission (3rd Edition). Islamabad: Ministry of Labour and Manpower and Overseas Pakistanis.

Pakistan, Government of (1992) Pakistan Integrated Household Survey 1991: Final Report. Islamabad: Federal Bureau of Statistics, Statistics Division.

Pakistan, Government of (1992a) Labour Force Survey 1990-91. Islamabad: Federal Bureau of Statistics, Statistics Division.

Pasha, A., and M. A. Altaf (1987) Return Migration in a Life-cycle Setting: An Exploratory Study of Pakistani Migrants in Saudi Arabia. Pakistan Journal of Applied Economics 6:1 1-21.

Rhoades, R. E. (1978) Intra-European Return Migration and Rural Development: Lessons from the Spanish Case. Human Organisation 37:2 136-147.

Ro, K. (1985) Workers of the Republic of Korea Returning from the Middle East and Their Families: Socio-economic Conditions and Problems. Paper presented at ESCAP Policy Workshop on International Migration in Asia and the Pacific, Bangkok, October 19-21.

Shah, N. M. (1994) An Overview of Present and Future Emigration Dynamics in South Asia. International Migration 32:2 217-268.

Stahl, C. W. (1986) Southeast Asian Labour in the Middle East. In F. Arnold and N. M. Shah (eds) Asian Labour Migration: Pipeline to the Middle East. London: Westview. 81-100.

Stahl, C. W. (ed) (1988) International Migration Today: Volume II Emerging Issues. Paris: UNESCO.

Stahl, C. W., and R. Appleyard (1992) International Manpower Flows: An Overview. Asia and Pacific Migration Journal 1: (3-4) 417-476.

Taylor, E. (1976) The Social Adjustment of Returned Migrants to Jamaica. In F. Henry (ed) Ethnicity in the Americas. The Hague: Mouton. 213-229. 